\title{
Growth Performance, Nutrients Digestibility and some Blood Constituents in Growing New Zealand White Rabbits Fed Diets Supplemented with Eucalyptus globules
}

Amany H. Waly' ${ }^{1}$ Ayat A. Ragab ${ }^{2}$; E. A. H. Quta ${ }^{1}$; Enayat H. Abo El-Azayem ${ }^{2}$ and Samia M. Mobarez ${ }^{1}$

${ }^{1}$ Department of Poultry Nutrition Research, Animal Production Research Institute, Agricultural Research Center, Giza, Egypt

${ }^{2}$ Department of Rabbit, Turkey and Water Fowl Breeding Research, Animal Production Research Institute, Agricultural Research Center, Giza, Egypt

E-mail of Corresponding Author: dr.amanyhwaly@gmail.com

\begin{abstract}
This study was conducted to investigate the effects of supplementing the rabbit diets with Eucalyptus globulus dried leaves (EGL) or its aqueous extract (EGE) on growth performance, nutrients digestibility and blood constituents. A total number of 225 weaned New Zealand White rabbits, six weeks old, were used in this experiment. Treatment groups were; a control diet $(C), \mathrm{T}^{1}$ and $\mathrm{T}^{2}$ were the control diet +0.25 or $0.5 \%$ dried eucalyptus leaves, respectively, $\mathrm{T}^{3}$ and $\mathrm{T}^{4}$ were the control diet +0.05 or $0.1 \%$ aqueous extract of eucalyptus leaves, respectively, The growth trail lasted for 8 weeks. At the end of the trial, digestibility nutrient trails were done and nutritive values were calculated, then rabbits were slaughtered and blood samples were obtained. The obtained results could be summarized as follows: Providing rabbit diets with EGL; EGA significantly $(\mathrm{P}<0.01)$ increased final live weight, body weight gain and, feed conversion ratio, especially at $0.25 \%$ EGL compared to the control. The best FCR were reported to the groups contain $0.25 \%$ EGL followed by $0.05 \%$ EGE. The digestibility coefficients for OM, CP and nutritive values in terms DCP and TDN of the experimental diets significantly increased with EGL and EGE feeding. Supplemented EGL or EGE to the diets significantly increased $(\mathrm{P}<0.05)$ values of hemoglobin concentration, RBC's, WBC's count and percentage of lymphocytes. Both EGL and EGE significantly increased blood total protein and albumin, also decreased triglycerides and total cholesterol and has no effect on creatinine and the activity of AST and ALT. It could suggested that using eucalyptus as feed additives for growing rabbits improve growth performance and digestibility, with no adverse effects on blood constituents.
\end{abstract}

Keywords: eucalyptus globules, rabbits, growth performance, digestibility, blood constituents

\section{INTRODUCTION}

The rabbit production is an important source of meat in Egypt. The rabbit farming provides additional income to small farmers which may be a source of their livelihood and increasing opportunity for employment to weaker section of rural community. In addition to high biological value amino acids of rabbit meat, it is high in protein, with low of cholesterol and sodium (Chakrabarti et al., 1999). Rabbits are very sensitive to enteric diseases especially when they are exposed to negative effects causing high losses such as weaning or heat stress (Shrivastava et al., 2012). Antibiotics were used to get rid of these problems and as growth promoter in animal feed, which improved health state and increased nutrient availability for rabbits, this lead to increasing growth performance (Pinheiro et al., 2004). However, the general intention to limit antibiotics in animal feed as growth promoter because of its side-effects, resistance and recent public perception about healthy food, besides, the ban on antibiotic growth stimulators in animal nutrition in the European Union, so new alternatives to antibiotics are needed (Marzo, 2001), such as herbal preparations (Abd El-Hady et al., 2013; Nosal et al., 2014 and N'Guessan et al., 2015).

Eucalyptus globules leaves are also known to contain bioactive products that showed anticariogenic (Ishnava et al., 2013), analgesic (Cimanga et al., 2002), antihistaminic and anti-inflammatory effects (Nagpal et al., 2010) and antioxidantive (Vratnica et al., 2011) activities. Eucalyptus globules leaves contain 1,8-cineole, eucalyptole and the other major components were alpha and beta piene, camphene, alpha-phellandren, P-cymene, crptone, alpha-terpineol, terpin 1-ene-4-ol, globulol and spathulenol (Chalchat, 1995).

Waly (2004) found that $0.4 \%$ dried Eucalyptus globulus leaves used as feed additives in broiler diets improved weight gain, feed conversion ratio, nutrients digestibility, sensory evaluation and economical efficiency. Also, Osman et al. (2007) concluded that $0.1 \%$ Eucalyptus globulus leaves improved performance per chicken. Silva $e t$ al., (2003) concluded that not water extracts of dried leaves of Eucalyptus spp traditionally used as analgesic, antiinflammatory and antipyretic remedies for the symptoms of respiratory infections, such as cold, flu, and sinus congestion. Sugimoto et al. (2005) found that the extracts of Eucalyptus globulus showed efficiency in preventing the oxidation process.

The aim of this trial was to test the effect of Eucalyptus globulus dried leaves or its aqueous extract growth performance, nutrients digestibility and blood constituents of growing weaned New Zealand White rabbits.

\section{MATERIALS AND METHODS}

\section{Plant material}

Eucalyptus leaves were air dried at room temperature in the shade for a few weeks to a final moisture content of $10.0 \%$. Then, the dried samples were ground in a blender so that the particle size will be between $0.8-0.9 \mathrm{~mm}$.

Preparation of aqueous extract

Weighting 100 gm of Eucalyptus globulus powdered leaves was infused in $500 \mathrm{ml}$ hot water for 4 hours then filtered with Whattman filter paper. Extracts were kept in Deep freezer at $-4^{\circ} \mathrm{C}$ for 48 hours, then introduced in freeze dryer till completely dried. The residue was weighed and the yield percentage was determined (Mittal and Aguwa, 1983).

Animal, management and dietary treatments

A total of 225 six-week-old unsexed weaned New Zealand White rabbits were randomly distributed into 5 treatments until 14 weeks of age, each contained three 
replicates (15 rabbits in each replicate). Dietary treatment included: a control diet (C), control diets plus 0.25 and $0.5 \%$ dried eucalyptus leaves (T1 and T2), and control diets plus 0.05 and $0.1 \%$ aqueous extract of dried eucalyptus leaves (T3 and T4). The basal diet (Table 1) was formulated according to NRC (1977). Rabbits were raised in cages which provided with a manual feeder and clean fresh water. Feed and water were provided ad-libitum. Rabbits were kept under the same hygienic and environmental conditions during the experimental period.

\section{Growth performance}

Live body weight (LBW) and feed intake (FI) were determined biweekly throughout the experimental period, and body weight gain (BWG) and feed conversion ratio (FCR) were calculated.

\section{Nutrient digestibility coefficients}

At the end week of the experimental period (14 weeks of age) four males in each treatment were used for determining nutrient digestibility coefficient of the tested diets. Rabbits were individually housed in metabolic cages; diets and fresh water were daily provided to the rabbit. Samples of feed and feces were collected for 3 days. Each animal feces was mixed and dried at $60 \mathrm{oC}$ for $24 \mathrm{~h}$. Chemical analyses of diets and feces were done according to the classical (AOAC, 1996). The nutritive values of the experimental diets were calculated according to Cheeke (1987).

Table 1. Composition and calculated chemical composition of the basal diet

\begin{tabular}{lccc}
\hline $\begin{array}{l}\text { Feed Ingredients } \\
(\%)\end{array}$ & \multicolumn{3}{c}{$\begin{array}{c}\text { Chemical composition } \\
\text { (\%DM basis) }\end{array}$} \\
\hline Alfalfa hay (12\%) & 27 & Dry Matter\% & 89.71 \\
Soybean meal (44\%CP) & 17.65 & Crude Protein\% & 17.14 \\
Barley & 20 & Crude Fiber\% & 12.75 \\
Yellow corn & 11.4 & Ether Extract\% & 2.37 \\
Wheat bran & 17.5 & Calcium \% & 1.19 \\
Molasses & 3 & Total Phosphorus \% & 0.8 \\
Limestone & 0.75 & Lysine \% & 0.89 \\
Dicalcium - phosphate & 1.9 & Methionine \% & 0.5 \\
Sodium chloride & 0.3 & Met + Cys \% & 0.79 \\
DL-Methionine & 0.2 & & \\
Mineral-vitamin premix & & & \\
Total & 0.3 & & \\
\hline
\end{tabular}

*Vit. And Min mixture: Each 3 kg contain: 6000000 IU Vit. A; 900000 IU Vit. D3; 40000 mg Vit. E; 2000 mg Vit. K3; 2000 mg Vit. B1; 4000 mg Vit. B2; 2000 mg Vit. B6; 10 mg Vit. B12; 50 mg Biotin; 10000 mg Pantothenic acid; 50000 Niacin; $3000 \mathrm{mg}$ Folic acid; $250000 \mathrm{mg}$ Choline; 8500 mg Mn; 50000 mg Zn; 50000 mg Fe; 200 mg I; 100 mg $\mathrm{Se}, 5000 \mathrm{mg} \mathrm{Cu}$, and $100 \mathrm{mg} \mathrm{Co}$.

\section{Haematologic and biochemical blood parameters}

At the end of the growth experiment, fresh blood samples from three rabbits of each treatment were collected and delivered to the laboratory within $2 \mathrm{~h}$ of collection to determine blood picture constituents. Feldman et al. (2000) method was used to count RBC's and WBC's. The hemoglobin concentration (HGB) $(\mathrm{g} / \mathrm{dl})$ and packed cells volume percentages was estimating according to Drew et al. (2004)

For biochemical blood parameters other blood samples (3 samples of each treatment) were collected in clean heparinized tubes. Plasma was obtained by blood centrifugation at $3000 \mathrm{rpm}$ for $20 \mathrm{~min}$ for analysis the blood biochemical parameters. Blood plasma total protein, albumin, triglycerides, total cholesterol, calcium, creatinine, uric acid, alanine amino transferase (ALT) and aspartate amino transferase (AST) were estimated by using commercial Kits. The globulin values were obtained by subtracting the values of albumin from the values of total proteins.

\section{Statistical analysis}

Data were analyzed using the GLM procedure of SAS software (SAS, 2001). Differences between treatments were assessed using Duncan's multiple range tests (1955) $(\mathrm{P}<0.05)$. The statistical model performed was as follow:

$$
\mathbf{Y}_{\mathrm{ik}}=\boldsymbol{\mu}+\mathbf{T}_{\mathbf{i}}+\mathbf{e}_{\mathrm{ik}}
$$

Where, $Y_{i k}=$ An observation, $\mu=$ Overall mean, $T_{i}=$ Effect of treatments $(i=1,2 \ldots .5), e_{i k}=$ random error

\section{RESULTS AND DISCUSSION}

\section{Growth performance}

Effects of supplemented diets with Eucalyptus dried leaves (EGL) or its aqueous extract (EGE) on growth performance are reported in Table 2. Dietary supplementation of EGL or EGE had no effect on LBW during 6-10wk of age, but during 12-14wk, LBW increased compared to the control. Rabbits fed diet supplemented with EGL or EGE had greater BWG compared to the control, and the highest value was reported to T1 (supplemented with $0.25 \%$ EGL) increased by $21.25 \%$ compared with C, furthermore, there were no significant differences among T2, T3 and T4. Supplemented diets with EGL or EGE had no effect on feed intake by at the age 6-12wk. Feed intake tended to be decreased for rabbits fed on supplemented diets compared to control diet. Rabbits fed different levels of EGL or EGE (T1, T2, T3 and T4) recorded an improvement $(\mathrm{P}<0.01)$ of FCR as compared to group C. However, T1 and T3 groups are better than other groups (C, T2 and T4). Supplemented diets with EGL or EGE improved FCR compared with the control by $22.48,16.67,19$ and $9.3 \%$ for T1, T2, T3 and T4, respectively. However, considering the entire experimental period, rabbit growth performance was improved by dietary treatments and growth parameters at slaughter were significantly different among groups, and the best results recorded to T2 which supplemented with $0.25 \%$ EGL.

Barbour et al. (2011) working with broilers and Hassan et al. (2011) with Japanese quail found that using eucalyptus as feed additives had a positive effect on growth performance, and this is may be due to the improvement in gut microflora and immunity system. Karimi et al. (2017) found that supplementing broiler diets with high level of Eucalyptus $(3 \mathrm{mg} / \mathrm{kg})$ decreased body weight gain. The improvement in growth performance with EGL and EGA supplementation may be due to that eucalyptus has a positive effect of on primary antibody response (Barbour et al. 2008).

\section{Nutrients digestibility coefficients}

Results of digestibility coefficients for DM, OM, $\mathrm{CP}, \mathrm{CF}, \mathrm{EE}, \mathrm{NFE}$, and nutritive values (DCP, and TDN) of the experimental diets showed that there were no significant differences between treatments on DM, CF, EE and NFE digestibility coefficients. Coefficients of OM and $\mathrm{CP}$ digestibility were significantly improved $(\mathrm{P}<0.05)$ with supplement under study (Table 3 ). There were no difference among treatments $\left(\mathrm{T}_{1}, \mathrm{~T}_{2}, \mathrm{~T}_{3}\right.$ and $\left.\mathrm{T}_{4}\right)$ in $\mathrm{CP}$ digestibility coefficients, whereas, coefficients of $\mathrm{CP}$ 
digestibility were significant increased $(\mathrm{P}<0.05)$ in comparison with control. Addition of EGL and EGE in rabbit diets significantly $(\mathrm{P}<0.05)$ increased nutritive values in terms of TDN and DCP compared to control diet. The positive effect of EGL and EGE on the digestibility traits may be due to that eucalyptus improved immunity in broiler (Barbour et al., 2011). Also, eucalyptus has an antioxidante activity (Vratnica et al., 2011) which reduces the oxidative stress and improves heath condition (Sahin $e t$ al., 2010; Starčević et al., 2015).

Table 2. Growth performance of growing rabbits fed experimental diets.

\begin{tabular}{|c|c|c|c|c|c|c|c|}
\hline \multirow{2}{*}{ Items } & \multicolumn{5}{|c|}{ Treatments } & \multirow{2}{*}{$\begin{array}{c}\text { Pooled } \\
\text { SE }\end{array}$} & \multirow{2}{*}{ Sig } \\
\hline & Control & $\mathbf{T}_{1}$ & $\mathbf{T}_{2}$ & $\mathbf{T}_{\mathbf{3}}$ & $\mathbf{T}_{4}$ & & \\
\hline \multicolumn{8}{|c|}{ Live body weight (LBW), g } \\
\hline 6 week & 703 & 705 & 698 & 702 & 698 & 1.01 & NS \\
\hline 8 week & 1108 & 1135 & 1200 & 1173 & 1115 & 32.48 & NS \\
\hline 10 week & 1547 & 1597 & 1598 & 1560 & 1588 & 8.01 & NS \\
\hline 12 week & $1908 b$ & $2000 a$ & $1987 a$ & $1963 \mathrm{ab}$ & $1948 \mathrm{ab}$ & 14.66 & $*$ \\
\hline 14 week & $2240 \mathrm{c}$ & $2568 \mathrm{a}$ & $2416 b$ & $2433 b$ & $2390 b$ & 32.6 & $* *$ \\
\hline \multicolumn{8}{|c|}{ Body weight gain (BWG), g } \\
\hline 6-8 week & 405 & 430 & 501.5 & 471.6 & 416 & 25.6 & NS \\
\hline $8-10$ week & $438.3^{\mathrm{ab}}$ & $461.7^{\mathrm{ab}}$ & $398.4^{\mathrm{ab}}$ & $386.67^{\mathrm{b}}$ & $473.3^{\mathrm{a}}$ & 18.13 & $*$ \\
\hline 10-12 week & 361.6 & 403.5 & 388.33 & 403.3 & 360 & 34 & NS \\
\hline 12-14 week & $331.7^{\mathrm{c}}$ & $568.4^{\mathrm{a}}$ & $430^{b}$ & $470^{\mathrm{b}}$ & $441.8^{b}$ & 20.65 & $* *$ \\
\hline Total & $1536.7^{\mathrm{c}}$ & $1863.3^{\mathrm{a}}$ & $1718.6^{\mathrm{b}}$ & $1731.8^{\mathrm{b}}$ & $1691^{\mathrm{b}}$ & 30.5 & $* *$ \\
\hline \multicolumn{8}{|c|}{ Feed intake (FI), $\mathrm{g}$} \\
\hline 6-8 week & 523.61 & 528.06 & 558.06 & 540.28 & 536.11 & 5.44 & NS \\
\hline 8-10 week & 675.19 & 617.33 & 639.44 & 586.11 & 683.33 & 27.03 & NS \\
\hline 10-12 week & 1223.33 & 1138.4 & 1157.67 & 1088.3 & 1188.3 & 40.9 & NS \\
\hline $12-14$ week & 1555 & 1375 & 1343.3 & 1411.7 & 1543.3 & 16.79 & NS \\
\hline Total & $3977.1^{\mathrm{a}}$ & $3658.7^{\mathrm{bc}}$ & $3698.5^{\mathrm{abc}}$ & $3626.4^{c}$ & $3951.1^{\mathrm{ab}}$ & 25.51 & $*$ \\
\hline \multicolumn{8}{|c|}{ Feed conversion ratio (FCR) } \\
\hline 6-8 week & 1.3 & 1.24 & 1.12 & 1.15 & 1.29 & 0.01 & NS \\
\hline 8-10 week & 1.55 & 1.34 & 1.62 & 1.52 & 1.45 & 0.03 & NS \\
\hline 10-12 week & 3.44 & 2.94 & 3 & 2.73 & 3.31 & 0.24 & NS \\
\hline $12-14$ week & $4.72 \mathrm{a}$ & $2.42 \mathrm{c}$ & $3.14 \mathrm{bc}$ & $3.01 \mathrm{bc}$ & $3.53 b$ & 0.15 & $* *$ \\
\hline Total & $2.58 \mathrm{a}$ & $2 c$ & $2.15 \mathrm{bc}$ & $2.09 \mathrm{c}$ & $2.34 b$ & 0.01 & $* *$ \\
\hline
\end{tabular}

a, $b$ and c: Means in the same row having different superscripts differ significantly .

C Control group, $T^{1} \mathrm{C}+0.25 \%$ EGL, $\mathrm{T}^{2} \mathrm{C}+0.50 \%$ EGL, $\mathrm{T}^{3} \mathrm{C}+0.05 \%$ EGE and $\mathrm{T}^{4} \mathrm{C}+0.10 \% \mathrm{EGE}$

Table 3. Nutrient digestibility coefficients and nutritive values of the experimental diets.

\begin{tabular}{|c|c|c|c|c|c|c|c|}
\hline \multirow{2}{*}{ Items } & \multicolumn{5}{|c|}{ Treatments } & \multirow{2}{*}{$\begin{array}{l}\text { Pooled } \\
\text { SE }\end{array}$} & \multirow{2}{*}{ Sig } \\
\hline & Control & $\mathbf{T}_{1}$ & $\mathbf{T}_{2}$ & $\mathbf{T}_{\mathbf{3}}$ & $\mathbf{T}_{4}$ & & \\
\hline$\overline{\mathrm{DM}}$ & 64.5 & 66.52 & 66.79 & 66.85 & 65.91 & 1.91 & NS \\
\hline $\mathrm{OM}$ & $76.6^{\mathrm{b}}$ & $76.86^{\mathrm{ab}}$ & $77.96^{\mathrm{a}}$ & $77.91^{\mathrm{a}}$ & $77.73^{\mathrm{ab}}$ & 0.37 & $*$ \\
\hline $\mathrm{CP}$ & $72.91^{\mathrm{b}}$ & $73.79^{a}$ & $74.42^{\mathrm{a}}$ & $73.84^{\mathrm{a}}$ & $74.62^{\mathrm{a}}$ & 0.33 & $*$ \\
\hline $\mathrm{CF}$ & 54.31 & 55.2 & 54.8 & 55.91 & 56.17 & 2.17 & NS \\
\hline $\mathrm{EE}$ & 60.48 & 61.31 & 61.73 & 61 & 61.59 & 0.81 & NS \\
\hline NFE & 81.16 & 81.51 & 82.63 & 82.72 & 82.57 & 0.61 & NS \\
\hline \multicolumn{8}{|c|}{ Nutritive value (\%DM) } \\
\hline DCP & $12.36^{\mathrm{b}}$ & $12.51^{\mathrm{a}}$ & $12.62^{\mathrm{a}}$ & $12.53^{\mathrm{a}}$ & $12.65^{\mathrm{a}}$ & 0.007 & ** \\
\hline TDN & $69.62^{\mathrm{c}}$ & $70.13^{\mathrm{bc}}$ & $70.85^{\mathrm{ab}}$ & $70.91^{\mathrm{b}}$ & $71.02^{\mathrm{a}}$ & 0.2 & $* *$ \\
\hline
\end{tabular}

$a, b$ and $c:$ Means in the same row having different superscripts differ significantly.

C Control group, $T^{1} \mathrm{C}+0.25 \%$ EGL, $T^{2} \mathrm{C}+0.50 \%$ EGL, $\mathrm{T}^{3} \mathrm{C}+0.05 \%$ EGE and $\mathrm{T}^{4} \mathrm{C}+0.10 \% \mathrm{EGE}$

\section{Hematological blood picture}

Results presented in Table 4 show that, values of hemoglobin concentration and RBC's count were significantly $(\mathrm{P}<0.05)$ increased in growing rabbits fed diet supplemented with EGL or EGE compared to the control. Also, counts of WBC's and its fractions of lymphocytes were significantly $(\mathrm{P}<0.01)$ increased as both forms of eucalyptus were included in the diets. Other WBC's fractions, $\mathrm{MCH}$ and $\mathrm{MCHC}$ were not significantly affected by treatments. AbdEl-Motaal et al. (2008) found that lymphocytes count increased with using eucalyptus as feed additives in laying hen, lymphocytes count is an index of stress conditions (Gross and Siegel, 1985), since lymphocytes decrease when hens are stressed. Besides, the lymphocyte is considered a good indicator of the increase in immune efficiency (Wieslaw et al., 2006).

\section{Metabolic blood parameters}

Blood plasma parameters of the experimental treatments (total protein, albumin, globulin, triglycerides, total cholesterol, creatinine and the activities of AST and ALT enzymes for 12 week old NZW rabbits are shown in Table 5. The obtained results show that the experimental treatments did not have significant effects on globulin, creatinine and AST and ALT activities. Total protein and albumin were significantly $(\mathrm{P}<0.01)$ increased, while triglycerides $(\mathrm{P}<0.01)$ and total cholesterol $(\mathrm{P}<0.05)$ were significantly decreased with EGL and EGE feeding. AbdEl-Motaal et al. (2008) reported that using eucalyptus as feed additives in laying hen significantly increased plasma globulin and reduced the activities of AST and ALT. Ibrahim et al. (2018) reported that eucalyptus oil reduced cholesterol concentration in broiler chickens 
Table 4. Hematological parameters of the studied treatments

\begin{tabular}{|c|c|c|c|c|c|c|c|}
\hline \multirow{2}{*}{ Items } & \multicolumn{5}{|c|}{ Treatments } & \multirow{2}{*}{$\begin{array}{c}\text { Pooled } \\
\text { SE }\end{array}$} & \multirow{2}{*}{ Sig } \\
\hline & Control & $\mathbf{T}_{1}$ & $\mathbf{T}_{2}$ & $\mathbf{T}_{3}$ & $\mathbf{T}_{4}$ & & \\
\hline$\overline{H e m o g l o b i n}(\mathrm{~g} / \mathrm{dl})$ & $8.77^{\mathrm{b}}$ & $9.93^{\mathrm{a}}$ & $10.73^{\mathrm{a}}$ & $9.87^{\mathrm{a}}$ & $10.1^{\mathrm{a}}$ & 0.31 & * \\
\hline Hematocrit value (HCT) \% & 47.27 & 47.05 & 48.43 & 47.59 & 48.74 & 1.01 & NS \\
\hline Red blood cells $\left(\mathrm{N} \times 10^{6} / \mathrm{cmm}^{3}\right)$ & $3.7^{\mathrm{c}}$ & $4.07^{\mathrm{bc}}$ & $4.67^{\mathrm{ab}}$ & $4.14^{\mathrm{bc}}$ & $4.97^{\mathrm{a}}$ & 0.17 & $*$ \\
\hline White blood cells $\left(\mathrm{N} \times 10^{3} / \mathrm{cmm}^{3}\right)$ & $6.5^{\mathrm{b}}$ & $7.37^{\mathrm{a}}$ & $7.5^{\mathrm{a}}$ & $7.4^{\mathrm{a}}$ & $7.33^{\mathrm{a}}$ & 0.06 & $* *$ \\
\hline Neutrophil (N) (\%) & 35.47 & 35.37 & 35.57 & 32.87 & 34.27 & 8.33 & NS \\
\hline Lymphocytes (L)(\%) & $51.47^{\mathrm{b}}$ & $54.3^{\mathrm{ab}}$ & $56.7^{\mathrm{a}}$ & $55.2^{\mathrm{a}}$ & $57.97^{\mathrm{a}}$ & 3.64 & $* *$ \\
\hline Monocytes (\%) & 5.13 & 4.8 & 4.73 & 5.27 & 5.2 & 0.27 & NS \\
\hline Eosinophils (\%) & 3.53 & 4.07 & 4.5 & 4.47 & 4.5 & 0.27 & NS \\
\hline Basophils (\%) & 0.36 & 0.41 & 0.38 & 0.36 & 0.38 & 0.002 & NS \\
\hline Packed cell volume (PCV) (\%) & 28.06 & 28 & 28.63 & 30.2 & 30.17 & 0.29 & NS \\
\hline Mean cell volume (MCV) (fl) & 85.3 & 83.6 & 84.9 & 83.3 & 82.2 & 0.41 & NS \\
\hline Mean corpuscular hemoglobin (MCH) (pg) & 29.2 & 31 & 30.1 & 31.6 & 30.3 & 0.34 & NS \\
\hline Mean corpuscular hemoglobin concentration $(\mathrm{MCHC})(\mathrm{g} / \mathrm{dl})$ & 24.2 & 26 & 24.6 & 24.6 & 24.3 & 0.09 & NS \\
\hline
\end{tabular}

a, $b$ and $c:$ Means in the same row having different superscripts differ significantly.

C Control group, $T^{1} \mathrm{C}+0.25 \%$ EGL, $\mathrm{T}^{2} \mathrm{C}+0.50 \%$ EGL, $\mathrm{T}^{3} \mathrm{C}+0.05 \%$ EGE and $\mathrm{T}^{4} \mathrm{C}+0.10 \%$ EGE

Table 5. Blood metabolic parameters of growing rabbits fed experimental diets.

\begin{tabular}{|c|c|c|c|c|c|c|c|}
\hline \multirow{2}{*}{ Items } & \multicolumn{5}{|c|}{ Treatments } & \multirow{2}{*}{$\begin{array}{c}\text { Pooled } \\
\text { SE }\end{array}$} & \multirow{2}{*}{ Sig } \\
\hline & Control & $\mathbf{T}_{1}$ & $\mathbf{T}_{2}$ & $\mathbf{T}_{3}$ & $\mathbf{T}_{4}$ & & \\
\hline Total protein $(\mathrm{g} / \mathrm{dl})$ & $5.47^{\mathrm{b}}$ & $5.83^{\mathrm{ab}}$ & $5.9^{\mathrm{a}}$ & $5.73^{\mathrm{ab}}$ & $6^{a}$ & 0.04 & $*$ \\
\hline Albumin (g/dl) & $3.8^{\mathrm{b}}$ & $3.97^{\mathrm{ab}}$ & $3.9^{\mathrm{ab}}$ & $4.03^{\mathrm{bc}}$ & $4.16^{\mathrm{a}}$ & 0.02 & $*$ \\
\hline Globulin (g/dl) & 1.67 & 1.87 & 2.03 & 1.7 & 1.83 & 0.04 & NS \\
\hline Triglycerides (mg/dl) & $34.67^{\mathrm{a}}$ & $34^{\mathrm{a}}$ & $32.67^{\mathrm{ab}}$ & $33^{\mathrm{ab}}$ & $30.67^{\mathrm{b}}$ & 1.8 & $*$ \\
\hline Total cholesterol (mg/dl) & $54.67^{\mathrm{a}}$ & $55.67^{\mathrm{a}}$ & $51^{\mathrm{ab}}$ & $49^{\mathrm{b}}$ & $46^{\mathrm{b}}$ & 7.33 & $* *$ \\
\hline Creatinine (mg/dl) & 1.08 & 1.87 & 1.08 & 1.1 & 1.05 & 0.01 & NS \\
\hline AST (IU/ml) & 37 & 38 & 36.67 & 36 & 39.67 & 12.13 & NS \\
\hline ALT (IU/ml) & 26 & 24.33 & 26 & 26.33 & 23.1 & 7.33 & NS \\
\hline
\end{tabular}

$a$, b and c: Means in the same row having different superscripts differ significantly.

C Control group, $\mathrm{T}^{1} \mathrm{C}+0.25 \%$ EGL, $\mathrm{T}^{2} \mathrm{C}+0.50 \%$ EGL, $\mathrm{T}^{3} \mathrm{C}+0.05 \%$ EGE and $\mathrm{T}^{4} \mathrm{C}+0.10 \% \mathrm{EGE}$

\section{CONCLUSION}

It could be concluded that eucalyptus globules leaves or its aqueous extract is a good feed additive in growing New Zeland growing rabbit diets as it improve growth performance, nutrients digestibility coefficients and had no adverse effects on blood constituents.

\section{REFERENCES}

AbdEl-Hady, A.M.; El-Ghalid O. A. H. and A. M. EL-Raffa (2013). Influence of herbal feed additives (DIGESTAROM) on productive performance and blood constituents of growing rabbits. Egyptian J. Anim. Prod. 50(1):27-37

AbdEl-Motaal, A. M.; Ahmed, A. M. H.; Bahakaim A. S. A. and M. M. Fathi (2008). Productive performance and immunocompetence of commercial laying hens given diets supplemented with eucalyptus. Int. J. Poult. Sci. 7 (5): 445-449,

AOAC, Association of Official Analytical Chemists (1996). Association of Official Analytical Chemists $16^{\text {th }}$ Edn., Gaithersburd, MD, USA.

Barbour, E. K.; Saadé, M. F.; Abdel-Nour, A. M.; Kayali, G.; Kidess, S.; Ghannam, R. B.; Harakeh, S. and H. Shaib (2011). Evaluation of essential oils in the treatment of broilers co-infected with multiple respiratory etiologic agents. Int. J. Appl. Res. Vet. Med., 9: 317-323.

Barbour, E. K.; Yaghi, R. H.; Shaib, H. A.; Tayeb, I. T. and F. T. Sleiman (2008). Evaluation of an essential oil in treatment of immunosuppressed-coinfected broilers. Am. Eurasian J. Sustain. Agric., 2: 212-218.
Chakrabarti, A.; Biswas, S. and A. Goswamy (1999). Rabbit Farming Kalyani Publishers, Rajendra Nagar, Ludhiana-8, Hariana.

Chalchat, J. C. (1995). Chemical composition of Eucalyptus globulus oils from the Montenegro coast and east coast of Spain. J. Essential Oil Res. 7:2, 147.

Cheeke, P.R. (1987). Rabbit Feeding and Nutrition. Academic Press, INC.

Cimanga K.; Kambu K.; Tona L.; Apers S.; De Bruyne T.; Hermans N.; Totte J.; Pieters L. and A. J. Vlietinck (2002). Correlation between chemical composition and antibacterial activity of essential oils of some aromatic medicinal plants growing in the Democratic Republic of Congo. J. of Ethno. pharmacology 79: 213- 220.

Drew, P.; Charles, R. J. S.; Trevor B. and L. John (2004). Oxford Handbook of Clinical Haematology. 2th Edition, Oxford University Press, USA.

Duncan, D. B. (1955). Multiple range and multiple F tests. Biometrics, 11: 1-42.

Feldman, B. F.; Zinkl, J. G. and N. C. Jain (2000). Schalm's veterinary hematology. lippincott Williams and Wilkins, Philadelphia, USA.

Gross, W. B. and P. B. Siegel (1985). Selective breeding of chickens for corticosterone response to social stress. Poult. Sci., 64: 2230-2233.

Hassan, M. S. H.; El Sanhoury, M. H.; Ali, W. A. H. and A. M. H. Ahmed (2011). Effect of using eucalyptus leaves as natural additives on productive, physiological, immunological and histological performance of laying Japanese quail. Egypt. Poult. Sci., 31: 305-329. 
Ibrahim, I. S. E.; Mukhtar M. A. and K. A. Mohamed (2018). Response of broiler chicks to different level of eucalyptus oil. World J. Pharmacy and Pharmaceutical Sci., 7 (4): 167-176.

Ishnava, K. B.; Chauhan, J. B. and M. B. Barad (2013). Anticariogenic and phytochemical evaluation of eucalyptus globules Labill. Saudi J. Biol. Sci. 20 (1): 69-74.

Karimi F. D. i.; Sadeghi, A.; Sheikhahmadi, G.; Habibian, A.; Raei, M. A. and K. Sobhani (2017). Effects of using eucalyptus (Eucalyptus globulus L.) leaf powder and its essential oil on growth performance and immune response of broiler chickens. Iranian J. of Vete. Res. 18(1):58, 60-62

Marzo, I. (2001). New Strategies in rabbit feed: Additives and alternatives to antibiotic use' $26^{\text {th }}$ Symp. ASESCU: Aveiro (Portugal), pp. 51-68.

Mittal G. C. and C. N. Aguwa (1983). A bortifacient effects of the root of Mormodica angustice pala. J. of Ethnopharm: 169 - 73.

N'Guessan B. B.; Dosso, K.; Gnangoran, B. N.; Amoateng, P.; Asiedu Gyekye, I. J. and A. P. Yapo (2015). Antibacterial and antispasmodic activities of a dichloromethane fraction of an ethanol extract of stem bark of Piliostigma reticulatum. J. Pharm. Bio. Sci; 7: 128-136.

Nagpal, N. G.; Shah, M.; Arora, N.; Shri, R. and Y. Arya (2010). Phytochemical and pharmacological aspects of eucalyptus genus, Inter. J. Pharmaceutical Sci. And Res. 1 (12):28-36.

Nosal, P.; Kowalska, D.; Bielański, P.; Kowal, J. and S. Kornaś (2014). Herbal formulations as feed additives in the course of rabbit subclinical coccidiosis. Ann Parasitol. 60: 65-69.

NRC (1977). National Research Council. Nutrient Requirements Of Rabbits. Nat. Acad. Sci., $1^{\text {st }}$ edition, Washington, Dc, USA.

Osman, A. M. R.; Hala M. Abd El-Wahed and Mona S. Ragab (2007). Performance and carcass characteristics of broiler chicks fed diets supplemented with some medicinal and aromatic plants. Fayoum J. Agric. Res. \& Dev., 18: (2): 11-22.
Pinheiro, V.; Mourão, J.; Alves, A.; Rodrigues, M. and M. Saavedra (2004). Effects of zinc bacitracin on performance, digestibility and caecal development of growing rabbits. Proc. $8^{\text {th }}$ World Rabbit Congress, Pueblá, Mexico, pp. 942-947.

Sahin, K.; Akdemir, F.; Orhan, C.; Tuzcu, M.; Hayirli, A. and N. Sahin (2010). Effects of dietary resveratrol supplementation on egg production and antioxidant status. Poult. Sci., 89, 1190-1198.

SAS (2001). User's Guide. Statistics. Statistical Analysis System. SAS Inst. Version 8.2, Cary NC. USA.

Shrivastava, A. K.; Tiwari, K. K.; Kumar R. and R. R. Jha (2012). Effects of feed additives on body weights at different ages in rabbit. J. Agri. Sci. Vol. 2(11), pp. 277-282.

Silva, J.; Abebe, W.; Sousa, S. M.; Duarte, V. G.; Machado, M. I. L. and F. J. A. Matos (2003). Analgesic and anti-inflammatory effects of essential oils of Eucalyptus. J Ethnopharmacol.;89:277-83. doi: 10.1016/j.jep.2003.09.007.

Starčević, K.; Krstulović, L.; Brozić, D.; Maurić, M.; Stojević, Z.; Mikulec, Ž. And T. Mašek (2015). Production performance, meat composition and oxidative susceptibility in broiler chicken fed with different phe-nolic compounds. J. Sci. of Food and Agric. 95, 1172-1178.

Sugimoto, K.; Suzuki, J.; Nakagawa, K.; Hayashi, S.; Enomoto, T.; Fujita, T.; Yamaji, R.; Inui, H. and Y. Nakano (2005). Eucalyptus leaf extract inhibits intestinal fructose absorption, and suppresses adiposity due to dietary sucrose in rats. Br. J. Nutr. 93: 957-963.

Vratnica D. B., Đakov T., Šuković D. and J. Damjanović (2011). Antimicrobial effect of essential oil isolated from Eucalyptus globulus Labill. From Montenegro. Czech J. Food Sci. 27(3): 277-284.

Waly, Amany. H. (2004). Use of some medicinal plants in broiler chickens. M.Sci. Thesis, Fac. of Agric. Sci., Ain Shams University, Egypt.

Wieslaw, P.S., Krystyna, M. Charon, Anna Winnicka and Joanna Gruszczynska (2006). Relationship between blood lymphocyte phenotype, drb 1 (mhc class ii) gene polymorphism and somatic cell count in ewe milk. Bulletin Veterinary Institute in Pulawy, 50: 7377.www.info@micro-plus.com

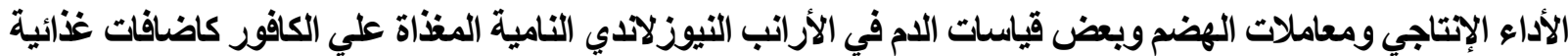

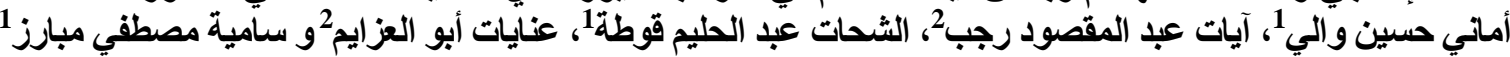

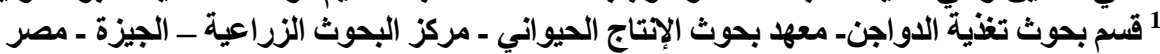

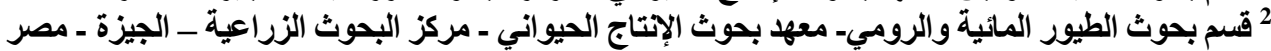

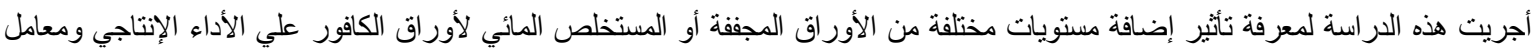

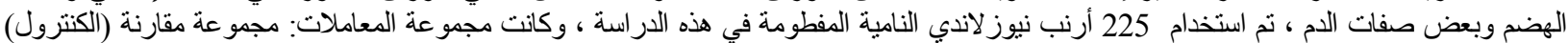

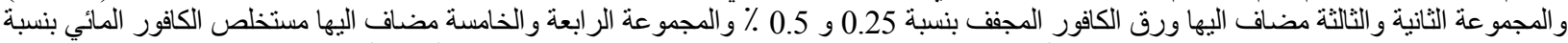

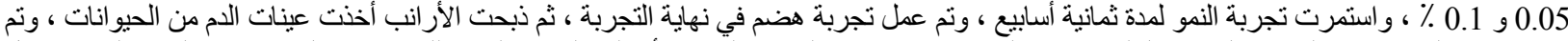

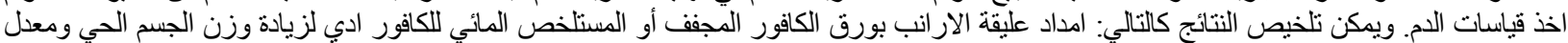

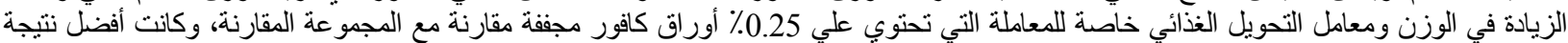

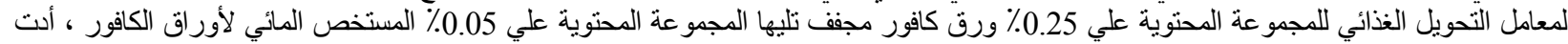

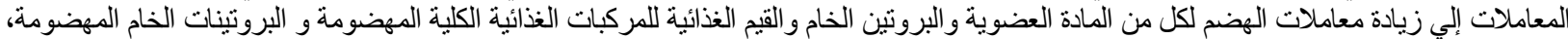

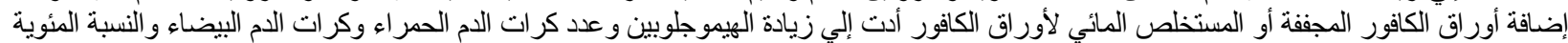

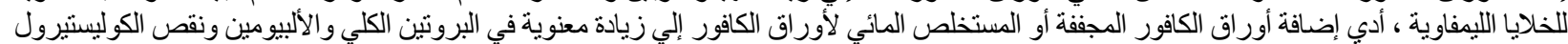

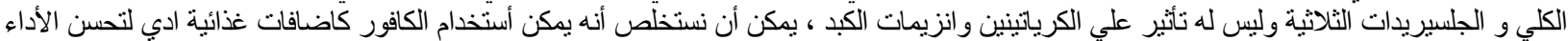

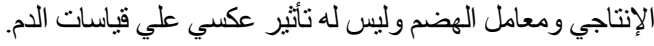

